\title{
Host-Feeding Preference and Diel Activity of Mosquito Vectors of the Japanese Encephalitis Virus in Rural Cambodia
}

\author{
Sébastien Boyer $\left.{ }^{1, *} \mathbb{(}\right)$, Benoit Durand ${ }^{2}{ }^{\oplus}$, Sony Yean ${ }^{1} \oplus$, Cécile Brengues ${ }^{3}$, Pierre-Olivier Maquart ${ }^{1}$, \\ Didier Fontenille ${ }^{1,3}$ (1) and Véronique Chevalier ${ }^{4,5}$ \\ 1 Medical and Veterinary Entomology Unit, Institut Pasteur du Cambodge, 5 Boulevard Monivong, \\ Phnom Penh 12201, Cambodia; sonyyean168@gmail.com (S.Y.); pomaquart@pasteur-kh.org (P.-O.M.); \\ didier.fontenille@ird.fr (D.F.) \\ 2 Laboratory for Animal Health, Epidemiology Unit, French Agency for Food, Environmental and \\ Occupational Health and Safety (ANSES), University Paris-Est, 94701 Maisons-Alfort, France; \\ benoit.durand@anses.fr \\ 3 MIVEGEC Unit, Institut de Recherche pour le Développement (IRD), Université de Montpellier, CNRS, \\ BP 64501, 34394 Montpellier, France; cecile.brengues@ird.fr \\ 4 Epidemiology and Public Health Unit, Institut Pasteur du Cambodge, 5 Boulevard Monivong, \\ Phnom Penh 12201, Cambodia; veronique.chevalier@cirad.fr \\ 5 International Center of Research in Agriculture for Development (CIRAD), UMR AS TRE, \\ 34090 Montpellier, France \\ * Correspondence: sebastien.boyer@pasteur.fr
}

\section{check for} updates

Citation: Boyer, S.; Durand, B.; Yean, S.; Brengues, C.; Maquart, P.-O.; Fontenille, D.; Chevalier, V. Host-Feeding Preference and Diel Activity of Mosquito Vectors of the Japanese Encephalitis Virus in Rural Cambodia. Pathogens 2021, 10, 376. https://doi.org/10.3390/pathogens 10030376

Academic Editor: Stephanie

L. Richards

Received: 29 January 2021

Accepted: 11 March 2021

Published: 21 March 2021

Publisher's Note: MDPI stays neutral with regard to jurisdictional claims in published maps and institutional affiliations.

Copyright: (c) 2021 by the authors. Licensee MDPI, Basel, Switzerland. This article is an open access article distributed under the terms and conditions of the Creative Commons Attribution (CC BY) license (https:// creativecommons.org/licenses/by/ $4.0 /)$
Abstract: Japanese Encephalitis (JE) is the most important cause of human encephalitis in Southeast Asia, and this zoonosis is mainly transmitted from pigs to human by mosquitoes. A better understanding of the host-feeding preference of Japanese encephalitis virus (JEV) major vectors is crucial for identifying risk areas, defining bridge vector species and targeting adapted vector control strategies. To assess host-feeding preference of JE vectors in a rural Cambodian area where JE is known to circulate, in 2017, we implemented four sessions of mosquito trapping (March, June, September, December), during five consecutive nights, collecting four times a night (6 p.m. to 6 a.m.), and using five baited traps simultaneously, i.e., cow, chicken, pig, human, and a blank one for control. In addition, blood meals of 157 engorged females trapped at the same location were opportunistically analyzed with polymerase chain reaction (PCR), using cow, pig, human, and dog blood primers. More than $95 \%$ of the 36,709 trapped mosquitoes were potential JE vectors. These vectors were trapped in large numbers throughout the year, including during the dry season, and from 6 p.m. to 6 a.m. Despite the apparent host-feeding preference of Culex vishnui, $C x$. gelidus, and $C x$. tritaenhyorhincus for cows, statistical analysis suggested that the primary target of these three mosquito species were pigs. Dog blood was detected in eight mosquitoes of the 157 tested, showing that mosquitoes also bite dogs, and suggesting that dogs may be used as proxy of the risk for human to get infected by JE virus.

Keywords: Japanese encephalitis virus; mosquitoes; host-feeding preference; Culex vishnui; Cambodia

\section{Introduction}

Japanese encephalitis (JE) is a vector borne zoonosis and one of the world's leading encephalitic diseases, particularly in the Asia-Pacific region [1]. The region hosts more than three billion people and the annual incidence of JE is estimated at about 67,900 cases in 24 countries [2]. JE is caused by the Japanese encephalitis virus (JEV) belonging to the Flaviviridae family [3]. The historically described JEV cycle involves water birds as wild reservoir, pigs as amplifying hosts [4-6], and mosquito species as vectors $[7,8]$. Domestic birds are suspected to be secondary reservoir hosts [9-11]. Proximity to rice fields and pig rearing, particularly backyard farming, have been identified as major risk factors of $\mathrm{JE}$ in humans $[12,13]$. JE is thus considered a rural disease. However, several studies in Cambodia [14], Hong-Kong [15], Japan [16], Malaysia [17], Taiwan [18], Thailand [19], 
and Vietnam [20] have shown that JEV and JEV vectors can be found in peri-urban areas. Humans, horses and cattle are considered dead-end hosts [7,21,22].

There are at least 25 mosquito species playing a role in the transmission of JEV [23]. In Asian countries, $C x$. tritaeniorhynchus, $C x$. vishnui, $C x$. fuscocephala, $C x$. gelidus, $C x$. whitmorei and Mansonia uniformis are considered the main vector species of JEV [21,24-31]. These mosquito species are widely distributed and highly abundant in SoutheastAsia [32-34]. They are also known for their opportunistic and generalistic trophic behavior [32,35-38].

Culex tritaeniorhynchus is considered the main vector of JEV transmission in Asia [28-30,39]. This mosquito species breeds mainly in the flooded rice fields [19,35,40-42]. Culex gelidus is described as the most important vector of JEV in India, Malaysia and Indonesia [33,43,44]. This species is able to breed in fresh and polluted water, and likely feeds on cattle [32,42]. The $C x$. pipiens complex mosquitoes such as $C x$. pipiens pipiens, $C x$. quinquefasciatus, $C x$. pipiens molestus considered as anthropophilic and urban mosquitoes are also described as JEV vectors $[1,45]$.

In Cambodia, JEV was isolated for the first time in 1965 from Cx. tritaeniorhynchus mosquito species in Phnom Penh capital [40]. Most Cambodians live in areas considered endemic due to the wide distribution of JEV vectors and pig farming areas. However, data on JEV vectors in Cambodia are scarce. A first study based on the seroconversion of sentinel pigs in Kandal province, on the outskirts of the capital Phnom Penh, showed an intensive JEV circulation during both dry and rainy seasons [14]. In this study, over $99 \%$ of trapped mosquitoes were identified as potential JEV vectors, namely $C x$. tritaeniorhynchus, $C x$. gelidus, $C x$. vishnui, and $C x$. quinquefasciatus [14]. A second study investigated the population dynamics of different mosquito vector species mentioned above and showed a high relative abundance throughout the year with a significant abundance peak at the end of the rainy season [46]. Lastly, in Cambodia again, JEV genotype I was detected in $C x$. tritaeniorhynchus [47].

"The host-feeding pattern of a mosquito population is the distribution of feeds taken on different vertebrate hosts" [48]. Genetically determined factors, environment and host availability impact feeding behavior of Culex mosquitoes [49,50]. Although pigs are central in the JE transmission, there is evidence that JEV virus can circulate in low pig density areas, suggesting the existence of secondary reservoirs such as domestic birds $[4,10,11]$. In these areas, the maintenance of JE could be facilitated by a multi-host system composed of pigs, ducks, chickens and vector populations exhibiting opportunistic feeding patterns [11].

A better understanding of these multi-hosts systems is needed to identify the main areas at risk. Our study aims at evaluating the respective feeding preferences of the main JE vectors in a rural Cambodian area where JE is endemic, and identify vector species that can be considered as bridge vectors between animal reservoirs and humans. To achieve this goal we implemented two complementary studies. In 2017, we first settled four sessions of mosquito trapping, during five consecutive nights, and using five baited traps simultaneously, i.e., cow, chicken, pig, human and a blank one for control. In addition, in 2018, a molecular host-analysis was performed on 157 engorged mosquitoes collected from the same site in 2016.

\section{Results}

2.1. Results of Baited Traps

2.1.1. Diversity of Mosquito Species and Relative Abundance

With baited-traps, at least 34 species of mosquitoes were captured, belonging to 8 genera: Aedes, Anopheles, Armigeres, Culex, Ficalbia, Lutzia, Mansonia, Mimomyia (Table 1). Only 550 male mosquitoes were trapped (1.5\%) and were discarded from data analysis. Anopheles genus represented at least 15 species and $11.2 \%$ of the trapped mosquitoes $(4,122 / 36,709)$. At least nine Culex species were identified representing $86.8 \%(31,866 / 36,709)$ of all mosquitoes. 
Table 1. List and total number of mosquitoes species caught by double nets with animal (cow, chicken, pig) and human baited traps during 5 consecutive nights for each month. The study was conducted from March to December 2017 in Kbal Chroy village in Cambodia. In bold, confirmed mosquito species vector of Japanese encephalitis virus.

\begin{tabular}{|c|c|c|c|c|c|}
\hline Mosquito Species & March & June & September & December & Total \\
\hline Aedes aegypti & 2 & & 1 & & 3 \\
\hline Aedes albopictus & & & 1 & 4 & 5 \\
\hline Aedes sp. & 1 & 3 & & 1 & 5 \\
\hline Total Aedes & 3 & 3 & 2 & 5 & 13 \\
\hline Anopheles barbirostris & 1 & & 87 & & 88 \\
\hline Anopheles barbumbrosus & 1 & 23 & 13 & 5 & 42 \\
\hline Anopheles campestris & 32 & 2 & 77 & & 111 \\
\hline Anopheles crawfordi & 2 & & 2 & & 4 \\
\hline Anopheles donaldi & 1 & & 1 & & 2 \\
\hline Anopheles hodgkini & 2 & & & 1 & 3 \\
\hline Anopheles indefinitus & 1 & 4 & 26 & & 31 \\
\hline Anopheles insulaeflorum & 2 & & & & 2 \\
\hline Anopheles nigerrimus & 2 & 2 & & & 4 \\
\hline Anopheles nitidus & 2 & & & 6 & 8 \\
\hline Anopheles peditaeniatus & 2320 & 18 & 93 & 80 & 2511 \\
\hline Anopheles pursati & 2 & & & 2 & 4 \\
\hline Anopheles roperi & 1 & & & & 1 \\
\hline Anopheles sinensis & 518 & 30 & 51 & 14 & 613 \\
\hline Anopheles sintonoides & 8 & & & & 8 \\
\hline Anopheles sp. & 543 & 38 & 47 & 62 & 690 \\
\hline Total Anopheles & 3438 & 117 & 397 & 170 & 4122 \\
\hline Armigeres kesseli & & & 1 & & 1 \\
\hline Armigeres subalbatus & 6 & 1 & 17 & 53 & 77 \\
\hline Armigeres sp. & 4 & 3 & & & 7 \\
\hline Total Armigeres & 10 & 4 & 18 & 53 & 85 \\
\hline Culex bitaeniorhynchus & & 3 & 2 & & 5 \\
\hline Culex fuscocephala & & & 5 & 1 & 6 \\
\hline Culex gelidus & 88 & 1074 & 667 & 719 & 2548 \\
\hline Culex nigropunctatus & & 1 & 6 & 2 & 9 \\
\hline Culex quinquefasciatus & 39 & 25 & 2 & 15 & 81 \\
\hline Culex sitiens & & 2 & & & 2 \\
\hline Culex tritaeniorhynchus & 3869 & 897 & 130 & 308 & 5204 \\
\hline Culex vishnui & 3745 & 8318 & 3213 & 8666 & 23,942 \\
\hline Culex sp. & 2 & 40 & & 27 & 69 \\
\hline Total Culex & 7743 & 10,360 & 4025 & 9738 & 31,866 \\
\hline Ficalbia sp. & 1 & & & & 1 \\
\hline Total Ficalbia & 1 & 0 & 0 & 0 & 1 \\
\hline Lutzia fuscana & & & & 2 & 2 \\
\hline Total Lutzia & 0 & 0 & 0 & 0 & 2 \\
\hline Mansonia annulifera & 1 & & 13 & 10 & 24 \\
\hline Mansonia bonneae & 2 & & & & 2 \\
\hline Mansonia indiana & & & 6 & & 6 \\
\hline Mansonia uniformis & 52 & 354 & 99 & 34 & 539 \\
\hline Mansonia sp. & & 22 & & 2 & 24 \\
\hline Total Mansonia & 55 & 376 & 118 & 46 & 595 \\
\hline Mimomyia luzonensis & & & 10 & 3 & 13 \\
\hline Mimomyia sp. & & 3 & & 2 & 5 \\
\hline Total Mimomyia & 0 & 3 & 10 & 5 & 18 \\
\hline unknown genus & 0 & 2 & 5 & 0 & 7 \\
\hline Total & 11,250 & 10,865 & 4575 & 10,019 & 36,709 \\
\hline Species number & 25 & 15 & 23 & 18 & 34 \\
\hline
\end{tabular}


We also identified at least 15 species of Anopheles, representing 30.6\% of the total number of mosquitoes in March and at least nine species (8.7\%) in September. At least four and six species of Culex were identified in March and September respectively, representing $34.5 \%$ and $55.7 \%$ of the mosquitoes. Culex mosquitoes were predominant in June and December representing $95.4 \%$ and $97.2 \%$ of trapped mosquitoes respectively. Among these Culex, $C x$. vishnui represented $76.6 \%$ and $86.5 \%$ respectively, $C x$. gelidus $9.9 \%$ and $7.2 \%$, and $C x$. tritaeniorhynchus $8.3 \%$ and $3.1 \%$. Within the Culex genus, the group of $C x$. vishnui was predominant with 3745 mosquitoes (33.3\%) in March, 8318 in June (76.6\%), 3213 in September $(70.2 \%)$ and 8666 in December (86.5\%). As a whole, the 4 main trapped Anopheles species, i.e., An. peditaeniatus, An. sinensis, An. Campestris, and An. barbirostris respectively represented only $6.8 \%, 1.7 \%, 0.3 \%$, and $0.2 \%$ of the total number of trapped mosquitoes.

Among the 34 identified species, six species are well-known JEV vectors: $C x$. bitaeniorhynchus, $C x$. fuscocephala, $C x$. gelidus, $C x$. quinquefasciatus, $C x$. tritaeniorhynchus, and $C x$. vishnui [24-31]. These six species represented $86.6 \%(31,786 / 36,709)$ of all the mosquitoes captured during the four entomological field missions, with high abundance levels (March: 68.8\%, June: 95.4\%, September: 87.8\%, and December: 96.9\%) (Table 1).

\subsubsection{Host-Feeding Preference and Biting Activity Pattern}

The effects of bait type (chicken, cow, human, and pig), month, time of collection, and position of the trap were studied for the most abundant and presumably important species in terms of JEV transmission, namely $C x$. gelidus, $C x$. tritaeniorhynchus and $C x$. vishnui (Table 2).

Table 2. Result of the negative binomial generalized linear models with the number of trapped mosquitoes $(C x$. vishnui, $C x$. tritaeniorhynchus and $C x$. gelidus) per trapping session as the outcome and bait type, collection time and position of trap as explanatory variables.

\begin{tabular}{|c|c|c|c|c|c|c|}
\hline \multirow{3}{*}{ Mosquito Species } & \multirow{3}{*}{ Variable } & \multirow{3}{*}{ Value } & \multicolumn{2}{|c|}{ Individual-Level Model } & \multicolumn{2}{|c|}{ BSA $^{\text {b-Level Model }}$} \\
\hline & & & Odds-Ratio & \multirow{2}{*}{$p$-Value } & Odds-Ratio & \multirow{2}{*}{$p$-Value } \\
\hline & & & $\left(95 \% \mathrm{CI}^{\mathrm{a}}\right)$ & & $(95 \% \mathrm{CI})$ & \\
\hline \multirow{13}{*}{ Culex vishnui } & \multirow{5}{*}{ Bait } & Pig & Ref. & & Ref. & \\
\hline & & Human & $0.5(0.4-0.8)$ & 0.002 & $0.4(0.3-0.7)$ & 0.001 \\
\hline & & Chicken & $0.09(0.06-0.1)$ & $<0.0001$ & $1.1(0.7-1.6)$ & 0.67 \\
\hline & & Cow & $1.6(1.1-2.4)$ & 0.016 & $0.7(0.5-1.1)$ & 0.08 \\
\hline & & Empty & $0.2(0.1-0.3)$ & $<0.0001$ & NA & \\
\hline & \multirow{8}{*}{ Hour } & December & Ref. & \multirow{4}{*}{$\begin{array}{c}0.002 \\
0.9 \\
<0.0001\end{array}$} & & \\
\hline & & March & $0.6(0.4-0.8)$ & & & \\
\hline & & June & $1.0(0.7-1.5)$ & & & \\
\hline & & September & $0.3(0.2-0.4)$ & & & \\
\hline & & 6 p.m. -9 p.m. & Ref. & & & \\
\hline & & 9 p.m. -0 a.m. & $1.0(0.7-1.4)$ & 0.9 & & \\
\hline & & 0 a.m. -3 a.m. & $0.7(0.5-0.9)$ & 0.02 & & \\
\hline & & 3 a.m. -6 a.m. & $0.4(0.2-0.5)$ & $<0.0001$ & & \\
\hline \multirow{13}{*}{$\begin{array}{c}\text { Culex } \\
\text { tritaeniorhynchus }\end{array}$} & \multirow{5}{*}{ Bait } & Pig & Ref. & & Ref. & \\
\hline & & Human & $0.2(0.1-0.4)$ & $<0.0001$ & $0.2(0.1-0.3)$ & $<0.0001$ \\
\hline & & Chicken & $0.05(0.03-0.08)$ & $<0.0001$ & $0.5(0.3-1.0)$ & 0.03 \\
\hline & & Cow & $1.4(0.8-2.4)$ & 0.2 & $0.6(0.4-1.1)$ & 0.07 \\
\hline & & Empty & $0.2(0.1-0.3)$ & $<0.0001$ & NA & \\
\hline & & December & Ref. & & & \\
\hline & & March & $14.3(8.6-23.7)$ & $<0.0001$ & & \\
\hline & Mionth & June & $4.6(2.7-7.9)$ & $<0.0001$ & & \\
\hline & & September & $0.5(0.3-0.9)$ & 0.008 & & \\
\hline & & 6 p.m. -9 p.m. & Ref. & & & \\
\hline & & 9 p.m. -0 a.m. & $0.6(0.4-1.0)$ & 0.03 & & \\
\hline & Hour & 0 a.m. -3 a.m. & $0.5(0.3-0.9)$ & 0.01 & & \\
\hline & & 3 a.m. -6 a.m. & $0.3(0.2-0.5)$ & $<0.0001$ & & \\
\hline
\end{tabular}


Table 2. Cont.

\begin{tabular}{|c|c|c|c|c|c|c|}
\hline \multirow{3}{*}{ Mosquito Species } & \multirow{3}{*}{ Variable } & \multirow{3}{*}{ Value } & \multicolumn{2}{|c|}{ Individual-Level Model } & \multicolumn{2}{|c|}{ BSA $^{b}$-Level Model } \\
\hline & & & Odds-Ratio & $p$-Value & Odds-Ratio & $p$-Value \\
\hline & & & $\left(95 \% \mathrm{CI}^{\mathrm{a}}\right)$ & & $(95 \% \mathrm{CI})$ & \\
\hline \multirow{16}{*}{ Culex gelidus } & \multirow{3}{*}{ Bait } & $\begin{array}{c}\text { Pig } \\
\text { Human }\end{array}$ & $\begin{array}{c}\text { Ref. } \\
0.5(0.3-0.8)\end{array}$ & 0.005 & $\begin{array}{c}\text { Ref. } \\
0.4(0.3-0.7)\end{array}$ & 0.0003 \\
\hline & & Chicken & $\begin{array}{c}0.09 \\
(006-015)\end{array}$ & $<0.0001$ & $1.1(0.7-1.7)$ & 0.7 \\
\hline & & $\begin{array}{l}\text { Cow } \\
\text { Empty }\end{array}$ & $1.5(0.9-2.3)$ & $\begin{array}{c}0.08 \\
<0.0001\end{array}$ & $0.6 \stackrel{(0.4-1.0)}{\text { NA }}$ & 0.04 \\
\hline & \multirow{4}{*}{ Month } & December & Ref. & & & \\
\hline & & March & $0.2(0.1-0.3)$ & $<0.0001$ & & \\
\hline & & June & $1.6(1.1-2.4)$ & 0.01 & & \\
\hline & & September & $1.1(0.7-1.7)$ & 0.7 & & \\
\hline & \multirow{4}{*}{ Hour } & 6 p.m. -9 p.m. & Ref. & & & \\
\hline & & 9 p.m.-0 a.m. & $1.3(0.9-1.9)$ & 0.2 & & \\
\hline & & 0 a.m. -3 a.m. & $1.1(0.8-1.7)$ & 0.5 & & \\
\hline & & 3 a.m. -6 a.m. & $0.2(0.1-0.3)$ & $<0.0001$ & & \\
\hline & \multirow{5}{*}{ Position $^{c}$} & Site 1 & Ref. & & & \\
\hline & & Site 2 & $1.7(1.0-2.7)$ & 0.03 & & \\
\hline & & Site 3 & $1.3(0.8-2.0)$ & 0.3 & & \\
\hline & & Site 4 & $3.1(1.9-4.9)$ & $<0.0001$ & & \\
\hline & & Site 5 & $2.0(1.3-3.2)$ & 0.003 & & \\
\hline
\end{tabular}

a: Confidence interval, ${ }^{\mathrm{b}}$ : Body Surface Area, ${ }^{\mathrm{c}}$ : Position of the trap.

The mosquito activity was highest from dawn, until 9 p.m. for $C x$. tritaeniorhynchus, and midnight for $C x$. vishnui and $C x$. gelidus (Table 2; Figure 1). The biting activity of $C x$. tritaeniorhynchus was maximum between 6 and 9 p.m. (OR $=0.6,0.5$ and 0.3, for 9 p.m.- 0 , 0-3 a.m. and 3-6 a.m. respectively). Compared to this trapping time slot, $C x$. vishnui was significantly less active from 0 to 3 a.m. (OR $=0.7, p=0.02$ ) and from 3 to 6 a.m. (OR $=0.4$, $p<0.0001$ ) and $C x$. gelidus, from 3 to 6 a.m. (OR $=0.2, p<0.0001$ ) (Table 2; Figure 1).
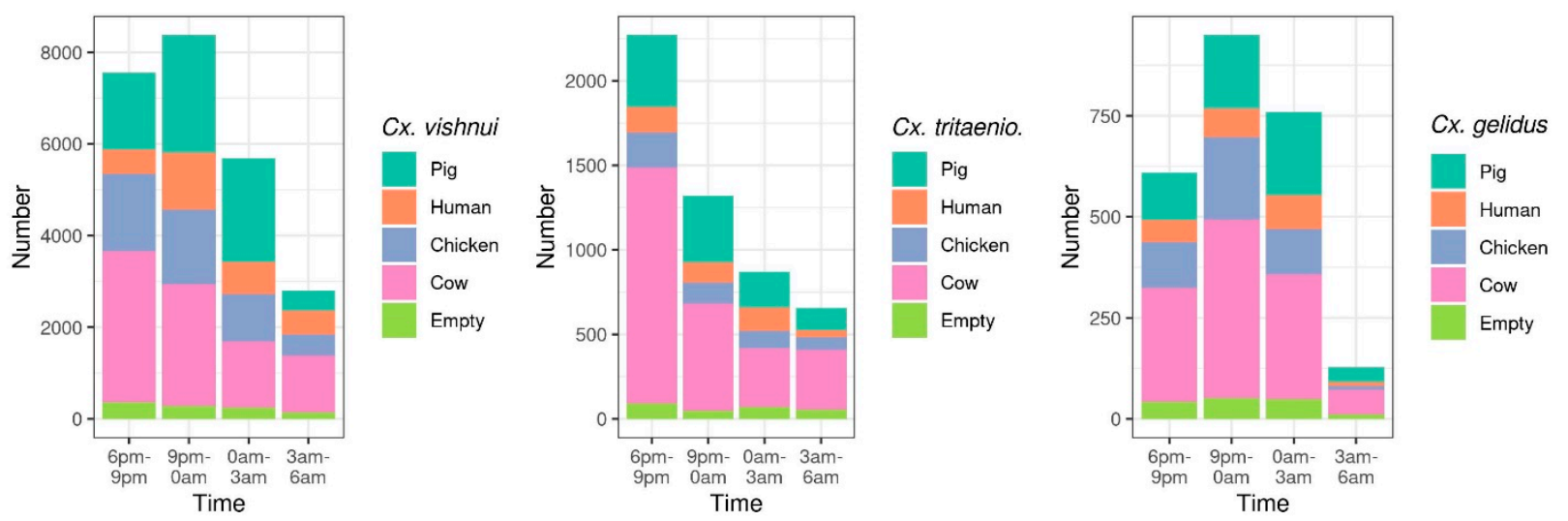

Figure 1. Mosquito abundance of the three main species Culex vishnui, Culex tritaeniorhynchus and Culex gelidus on different baits (pig, human, chicken, cow and empty) at different time of collection during the night (every 3 h from 6 p.m. to 6 a.m.). Y-axis have different scales.

The number of trapped mosquitoes also varied significantly with the month of trapping (Table 2; Figure 2). Cx. vishnui was significantly more abundant in December and June than in March $(\mathrm{OR}=0.6, p=0.002)$ and September $(\mathrm{OR}=0.3, p<0.0001)$. C $x$. tritaeniorhynchus was the most abundant in March $(\mathrm{OR}=14.3, p<0.0001)$ and less abundant in September $(\mathrm{OR}=0.5, p=0.008)$. C $x$. gelidus was significantly less abundant in March $(\mathrm{OR}=0.2, p<0.0001)$ compared to the other months. 

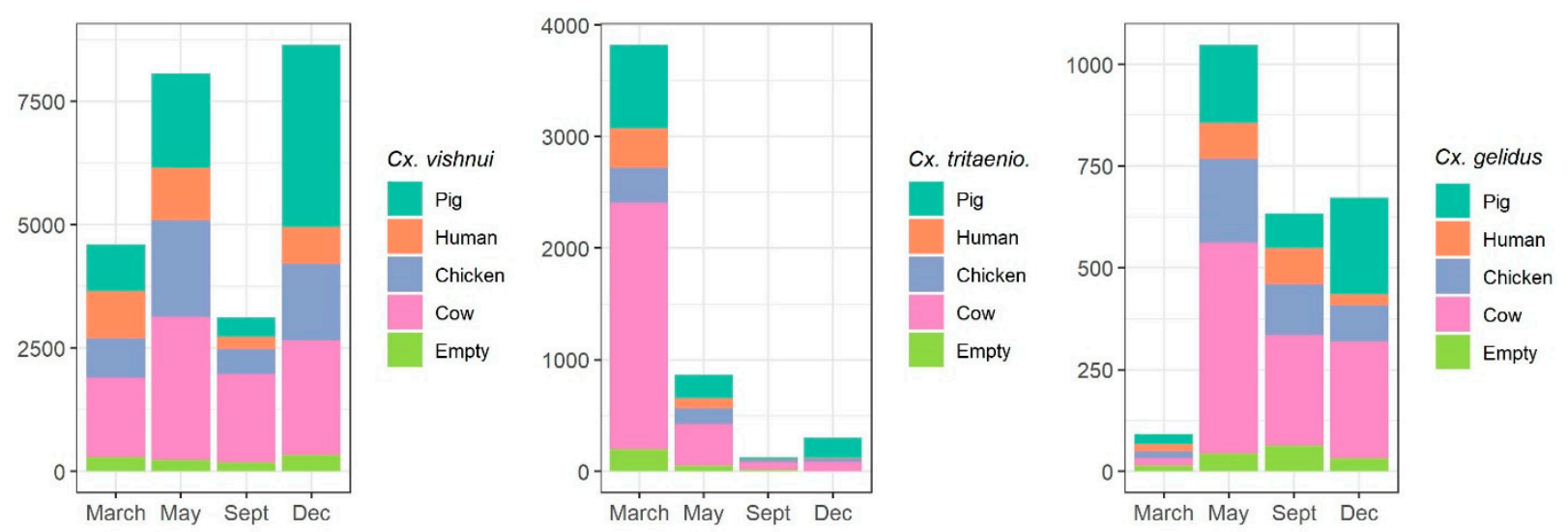

Figure 2. Mosquito abundance of the three main species Culex vishnui, Culex tritaeniorhynchus and Culex gelidus on different baits (pig, human, chicken, cow and empty) during the 4 trapping months (March, June, September and December). Y-axis represents the total number of collected mosquitoes. Y-axis have different scales.

Regarding the feeding preference, the three mosquito species were attracted by the four different host species (Figure 2). Whatever the mosquito species, individual-level models showed that, cow-and pig-baited traps were significantly more attractive than human-,chicken-and blank-baited traps (Table 2). Compared to pig, the odd-ratios were higher for cow (1.6 for $C x$. vishnui, 1.4 for $C x$. tritaeniorhynchus and 1.5 for $C x$. gelidus) and always significantly less than 1 for human-, chicken-, and blank-baited traps (Table 2).

However, these results changed when considering Body Surface Area (BSA) level models: pig- and chicken-baited traps were significantly more attractive than human-baited traps (Table 2). For a given BSA unit, $C x$. vishnui and $C x$. gelidus were more attracted by pigs and chickens, and $C x$. tritaeniorhynchus by pigs. The difference between cow and pig was significant only for $C x$. gelidus (OR: 0.6, $p=0.04$ ). Although not significant, the same trend was observed for $C x$. vishnui $(\mathrm{OR}=0.7 ; p=0.08)$ and $C x$. tritaeniorhynchus $(\mathrm{OR}=0.6$; $p=0.07$ ) (Table 2).

Compared to Site 1, we caught more $C x$. gelidus individuals on Site $2(\mathrm{OR}=1.7$; $p=0.03), 4(\mathrm{OR}=3.1 ; p<0.0001)$ and $5(\mathrm{OR}=2.0 ; p=0.003)($ Table 2$)$.

\subsection{Blood Meal Analysis of Engorged Mosquitoes}

PCR was performed on blood meals of female mosquitoes captured with light traps in the same area the year before the host-feeding preference experiment. In 2016, 157 engorged female mosquitoes were collected, representing at least seven mosquito species belonging to three genera (Table 3). A total of 118 individual mosquitoes were identified to species level and 41 mosquitoes were identified only to the genus level. Some specimens were not identified to the species level due to the quality of the field samples caught with light traps. The mosquitoes were Anopheles sinsulaeflorumor/bangalensis $(n=4), C x$. gelidus $(n=26), C x$. quinquefasciatus $(n=6), C x$. tritaeniorhynchus $(n=20), C x$. vishnui $(n=52)$, Mansonia annulifera $(n=4)$ and Ma. uniformis $(n=6)$ (Supplementary Table S1). Surprisingly, none of the PCR realized with human primers and chicken primers were positive. Sixty eight individuals were engorged with cow blood (43.3\%), 47 with pig blood (29.9\%), and 8 mosquitoes ( $C x$. gelidus, $C x$. tritaeniorhynchus, $C x$. vishnui and $C x$. sp) were engorged with dog blood (5.1\%) (Table 3). More specifically, $C x$. gelidus $(17 / 24)$ and $C x$. quinquefasciatus $(4 / 6)$ were mainly found with cow blood, while $C x$. tritaeniorhynchus and $C x$. vishnui were found mainly with pig or cow blood (Table 3). Finally, blood meals of 34 mosquitoes (21.7\%) were taken from hosts that could not be identified with our primers. 
Table 3. Blood-feeding analysis of blood-fed mosquitoes analyzed by PCR.

\begin{tabular}{ccccc}
\hline Mosquito Species $(\mathbf{N}=\mathbf{1 5 7})$ & Dog & Pig & Cow & Negative \\
\hline Anopheles sinsulaeflorumor/bangalensis & 0 & 1 & 3 & 0 \\
Anopheles sp. & 0 & 0 & 0 & 1 \\
Culex gelidus & 1 & 5 & 17 & 1 \\
Culex quinquefasciatus & 0 & 0 & 4 & 2 \\
Culex sp. & 3 & 17 & 11 & 9 \\
Culex tritaeniorhynchus & 1 & 8 & 9 & 2 \\
Culex vishnui & 3 & 15 & 18 & 16 \\
Mansonia annulifera & 0 & 1 & 6 & 3 \\
\hline Total & 8 & 47 & 68 & 34 \\
\hline
\end{tabular}

\section{Discussion}

Previous entomological studies performed in rural and peri-urban Cambodian areas showed a high mosquito species diversity $[46,51]$. Our results confirm the presence of a significant number of mosquito species present around human habitats. In terms of number of species, the genus Anopheles has the highest species diversity in our study. This genus is known to be very diverse in Southeast Asia [52]. The presence of cultivation, in particular rice paddies, as well as the presence of many rivers, also known to be breeding sites frequented by Anopheles can explain this high diversity. Culex genus is ultra-dominant and represents almost $90 \%$ of mosquitoes caught in baited traps, with $C x$. vishnui, $C x$. gelidus and $C x$. tritaeniorhynchus. $C x$. vishnui has already been described as predominant in Cambodia [46] and is known to be involved in the transmission of JEV even if no vector competence study has yet demonstrated it formally. Cx vishnui was detected positive with JEV in India, Malaysia and India [33,53-56]. JEV was isolated from $C x$. gelidus in India $[33,57]$ and in pig farms in Malaysia [58]. JEV was isolated from $C x$. tritaeniorhynchus in Java [59], Indonesia [60], India [57], Vietnam [23], Malaysia [58], Taiwan [61], and Cambodia [47]. Interestingly, the fourth most abundant species is Anopheles peditaeniatus in which, also, JEV was already isolated in India [57]. These four species represented $93 \%$ of the 36,709 trapped mosquitoes.

$C x$. vishnui, $C x$. gelidus and $C x$. tritaeniorhynchus species were trapped throughout the year, suggesting that JEV can circulate even during the cold season, from November to February. The baited double net trap methodology was used with success to trap mosquito's vector of Plasmodium sp. in Lao PDR [62] and Cambodia [63]. In addition, the vectors were active during each stretch of the night, including the first one from 6 to 9 p.m. In Cambodia, rural inhabitants are active (cooking, dining, showering) outside, generally under the stilt house until 9-10 p.m. This critical timeframe could be a preferential moment for exposure to JEV vectors. Indeed, Culex mosquitoes are classically described as exophilic and nocturnal mosquitoes [48]. Consequently, sleeping under a mosquito net is useful but not enough to protect humans against JE transmission.

The feeding behavior of mosquitoes is dependent on host preference and host selection $[64,65]$ and influenced by several factors such as carbon dioxide, host-skin volatiles and compound blends in the specific case of host seeking [66]. Host selection is defined as the feeding pattern in nature, represented by the relative frequency of different blood meal sources of a mosquito population in time and space. In the present survey, host selection is assessed using the individual-based model. Host preference is defined as the trait to preferentially select a particular vertebrate host as a food source, over the other species that are equally available [64]: this was assessed using the BSA-level model. Although the host preference is determined by numerous intrinsic physiological characteristics of the vector [67-69], host selection is primarily influenced by ecological [65] and chemical factors such as fatty acids, n-aliphatic carboxylic acids, lactic acid playing an important role in differential olfactory attraction [66]. Both results are important in terms of host-feeding preference. 
Our trapping results confirm that Culex are opportunistic mosquitoes. The 3 species of concern were attracted by the four baits. However, and as expected, we observed a significant difference in conclusion between the two statistical analyses. Whatever the mosquito species, individual-level models showed that, cow- and pig-baited traps were significantly more attractive than human-, chicken- and blank-baited traps. Indeed, in the field, we observe a greater number of mosquitoes around a cow than a pig, mainly for its significant release of heat and carbon dioxide. Even if $\mathrm{CO}_{2}$ was certainly the best attractant for mosquito host location, especially for zoophilic mosquitoes [70,71], the skin volatile compounds of the different species, especially for pig and cow, certainly plays a more specific attractant role at short distances as already demonstrated on another Culex species, Culex quinquefasciatus [72].

According to BSA-level model, $C x$. vishnui and $C x$. gelidus species are primarily attracted by pigs and chicken. This result is consistent with the literature describing $C x$. vishnui having pigs and birds as preferred hosts $[73,74]$, but being able to feed on cow and man in the absence of its main hosts [75]. In Taiwan, Cx. vishnui was reported to feed on pigs [76] and in Thailand on buffalo and cattle [26]. For Cx. gelidus, this same generalist, opportunistic behavior with a zoophilic preference was observed during our study. This result is confirmed in the literature, citing it as a highly general mosquito with a preference for cow and pig [77]. It should also be noted that this mosquito is considered to be zoophilic although it can conveniently feed on humans [78]. For Cx. tritaeniorhynchus, the BSA-level model shows a strong preference for pigs then cows and chickens, and then humans. These zoophilic preferences of mosquitoes for cows and pigs have been described since 1959 [73]. In the absence of cattle, the species is attracted to human but is slow to feed, whereas in the presence of cattle, man is almost completely ignored [73].

Results of blood meal PCR analyses confirm the statistical analyses performed on trapping data, despite the very low number of mosquitoes. PCR results also showed that the main potential JEV vector species in Cambodia can feed on dogs. Experimentally, infected dogs showed very low viremia suggesting that dogs are not involved in JEV circulation [79]. However, dogs live alongside humans and, as suggested by the results of a serological survey carried out in the same area [11], they could be a relevant indicator of the risk for humans to get infected by JEV. In Kandal province where the present survey was carried out, the dog/human ratio was estimated to be 1:4 on average (V. Chevalier, pers.com on 20 January 2021). Since dogs are supposed to be a dead end host, they may participate with cows to a zooprophylactic effect in areas where the ratio dog/human is high, and to some extent reduce mosquito predation on humans.

Despite the existence of human vaccines, JE remains a major public health problem in Southeast Asia, especially in children. In Cambodia, the opportunistic behavior of JE vectors may facilitate JE circulation within a multi-host system, especially in lowpig densities areas. Estimating the respective role of these vectors according to their environment will be an important step to better understand this multi-host system, to refine the identification of areas at risk and improve prevention, and control strategies in the future.

\section{Materials and Methods}

\subsection{Study Area}

The study was conducted in Kbal Chhroy village, Porti Ban commune, Koh Thom District, Kandal province, Cambodia (11.219846 ${ }^{\circ}$ N, $105.039502^{\circ}$ E, WGS 84 system). The study site was located in a house backyard, near the Bassac River, and a pig farm (around 350 located at $200 \mathrm{~m}$, on the other side of the road). The surrounding landscape, mainly rural, was dominated by crops (mango, corn, beans etc.) and rice cultivation. The owner also reared pigs, cows, and chickens at the backyard of the household, located at around $20 \mathrm{~m}$ of the experiment. 


\subsection{Bait Trapping Survey}

\subsubsection{Trapping}

Adult mosquitoes were trapped in 2-6 March, 21-25 June, 11-15 September and 4-8 December 2017, using five double net baited traps: one cow, one pig, one human, eight chickens, and 1 empty trap for control. We used eight chickens to minimize a potential bias due to an increased $\mathrm{CO}_{2}$ attractiveness of pig/cow/human compared to chickens.

The trap consisted in a classic baited double net. One untreated mosquito net (size $X=450, Y=286 \mathrm{~cm}, \mathrm{H}=220 \mathrm{~cm}$ ) was raised slightly above the ground (around $30 \mathrm{~cm}$ ) to allow mosquitoes to enter the trap from its base. Another untreated mosquito net (size $X=280, Y=200 \mathrm{~cm}, \mathrm{H}=190 \mathrm{~cm}$ ) was settled under the first one, protecting the bait from mosquito bites. The size of cage-trap was equal for all the treatments. The same animal was used during the entire night and for each session. The cow was partially encaged and tied as normally, the pig and the chicken were in their habitual cage. Animals were under the same standard conditions as usual.

The traps were used during five consecutive nights, with a turn-over of the baits at the different positions (Site 1 to Site 5, located $4 \mathrm{~m}$ from each other) designed as a carre latin. The area of each trap was cleaned every morning: removing of cow, pig and chicken faecal material and ground washed from with fresh water.

The baits were settled at 06.00 p.m., and mosquito collection was performed every $3 \mathrm{~h}$ at 09.00 p.m., 00.00 a.m., 03.00 a.m. and 06.00 a.m. by two technicians who caught mosquitoes trapped between the two nets using manual aspirators. Collected mosquitoes were killed with an insect spray and stored in an icebox at $+4{ }^{\circ} \mathrm{C}$.

\subsubsection{Mosquito Identification}

Mosquitoes were identified on site under stereomicroscope (SZ61 Olympus, Tokyo, Japan) and using morphological mosquito identification keys of Southeast Asia countries [80-85]. After identification, mosquitoes were sorted in $1.5 \mathrm{~mL}$ Eppendorf tube (Thermo Scientific, Waltham, MA, USA) according to the trap site, date and hour of catch, bait type, mosquito species, blood fed status (engorged or not), and sex, with a maximum of 30 individuals per tube.

\subsubsection{Statistical Analysis}

We focused the analysis on the well-known JEV vectors, namely $C x$. gelidus, $C x$. tritaeniorhynchus and $C x$. vishnui [24-31], which were collected in more than $10 \%$ of capture sessions (a capture session being, here, a combination of a date, a collection time, a trap position and a bait type). For each species, we used a generalized linear model to analyze the variations of the number of captured mosquitoes according to the bait type (chicken, pig, cow, human or blank), the month (December, March, June or September), the collection time (6 p.m.-9 p.m., 9 p.m.- 0 a.m., 0 a.m. -3 a.m., or 3 a.m. -6 a.m.), and the position of the trap (five distinct position names, i.e., Site 1 to Site 5 ).

Two error distributions are commonly used to model count data such as numbers of trapped mosquitoes: the Poisson distribution and the negative binomial distribution. Because of the strong overdispersion observed with Poisson distributions, we chose using negative binomial error distributions. When modelling count data, the use of an offset allows associating each observation with a level of "exposure". The statistical model is then used to quantify the effect of the explanatory variables per unit of "exposure". In our case, the "exposure" is the quantity of baits used. We fitted two groups of models, corresponding to two distinct measures of this quantity. In "individual-based" models, the offset was the logarithm of the number of individuals used as baits ( 8 for chicken and 1 for the 4 other baits). The estimated effect of the type of bait (i.e., species) then indicated the increase of the number of trapped mosquitoes induced by an additional individual of that species in the trap. In "body surface area (BSA)-based" models, we used the logarithm of the total BSA as an offset, based on the following values of BSA: $0.13 \mathrm{~m}^{2}$ for a chicken, $1.51 \mathrm{~m}^{2}$ for a pig, $3.45 \mathrm{~m}^{2}$ for a cow, and $1.81 \mathrm{~m}^{2}$ for a human [86,87] (blank trap collections were discarded 
for this part of the analysis). The estimated effect of bait type in this case corresponded to the increase of the number of trapped mosquitoes induced by an additional square meter of BSA of the species in the trap. Note that changing the measure of bait quantity (i.e., the offset) only affected the estimated effect of the bait type, not the month, time of collection, and trap position. Pigs were chosen as the reference ("Ref.") for the model while 'December', '6 p.m.-9 p.m.' and 'site 1' were arbitrary selected as reference by being respectively the first month of collection, the first quarter of the night session, and the first site.

All the statistical analyses were performed using R v. 3.6.3 [88], packages MASS version 7.3.53 [89], ggplot2 v. 3.3.2 [90], and cowplot v. 1.1.0 [91].

\subsection{Analysis of Blood Fed Mosquitoes}

\subsubsection{Blood-Fed Specimens}

Blood fed mosquitoes were caught in the same area, Kbal Chhroy village, at the same household in 2015-2016 using light traps [46] and conserved at $-20^{\circ} \mathrm{C}$. In 2018 , all bloodfed females $(n=157)$ were analyzed with polymerase chain reaction (PCR), using specific primers for the most abundant animals living in the close vicinity of the household, namely pigs, human, cows, chickens, and dogs.

\subsubsection{DNA Extraction}

Mosquitoes were separated in $1.5 \mathrm{~mL}$ Eppendorf tube with two iron beads, $200 \mu \mathrm{L}$ of Cetyl TrimethylAmmonium Bromide (CTAB, Sigma-Aldrich, Saint-Louis, MO, USA) to grind the body for $4 \mathrm{~min}$ in the Tissuelyser II QIAGEN (Program 2, Fq 29). After a centrifugation of $15 \mathrm{sec}$ at $12,000 \mathrm{rpm}$ and a $65{ }^{\circ} \mathrm{C}$ water bath during $5 \mathrm{~min}, 200 \mu \mathrm{L}$ of chloroform (Sigma-Aldrich) were added, and centrifuged again for $5 \mathrm{~min}$. The supernatant was transferred in another $1.5 \mathrm{~mL}$ tube and we added $200 \mu \mathrm{L}$ of isopropanol, mixed and centrifuged for $15 \mathrm{~min}$. Then, we removed the isopropanol, add $200 \mu \mathrm{L}$ of ethanol 70\%, centrifuged for $5 \mathrm{~min}$, and removed ethanol. After drying the tubes, we added $20 \mu \mathrm{L}$ of $\mathrm{H}_{2} \mathrm{O}$ pure water for PCR. All samples were stored in the freezer at $-20{ }^{\circ} \mathrm{C}$ after a final DNA CTAB extraction [92].

\subsubsection{Polymerase Chain Reaction Assay}

Two different PCRs were used to identify the animal origin of blood meals: one multiplex able to detect human, cow, pig and dog blood, and a uniplex for chicken $[93,94]$. The $25 \mu \mathrm{L}$ reaction mixture contained $1 x$ buffer, $2.5 \mathrm{mM} \mathrm{MgCl}$, $0.2 \mathrm{mM}$ dNTP, 10 pmoles UNREV 1025, 5 pmoles of Dog 368F primers, Human 741F primers, Cow 121F primers, Pig 573F primers, and $0.5 \mathrm{U}$ of Taq DNA polymerase with $\mathrm{H} 2 \mathrm{O}$, and DNA diluted 1/10 [93]. The amplification conditions adapted from Kent et al. [93] were a 1 st step at $94{ }^{\circ} \mathrm{C}$ for $5 \mathrm{~min}$, a 2 nd step of 35 cycles of $30 \mathrm{~s}$ at $94{ }^{\circ} \mathrm{C}, 1 \mathrm{~min}$ at $58^{\circ} \mathrm{C}$ and $1 \mathrm{~min}$ at $72{ }^{\circ} \mathrm{C}$, and a final step at $72{ }^{\circ} \mathrm{C}$ for $10 \mathrm{~min}$. Chicken 470F primers were used alone [94]. Polymerase Chain Reaction (PCR) products were analyzed using a 2.5\% agarose gel (Tris Acetate EDTA) and visualized under U.V. (Molecular Imager, Bio-Rad, Hercules, CA, USA) [93]. Ethidium bromide-stained agarose gel showed whole blood of mosquitoes fed on each blood source. Control products amplified whole blood of chicken (290 bp), human (350 bp), pig (400-500 bp), cow (600-700 bp) and dog (700-800 bp).

Supplementary Materials: The following are available online at https:/ /www.mdpi.com/2076-081 7/10/3/376/s1, Table S1: Provenance and date of catch of mosquitoes analyzed by PCR. Blood-fed mosquitoes were catch in Kbal Chrroy village.

Author Contributions: Conceptualization, S.B.; data curation, B.D., V.C., S.Y. and C.B.; formal analysis, V.C., S.B., B.D. and C.B.; funding acquisition, D.F. and V.C.; investigation, S.B. and S.Y.; methodology, S.B.; project administration, S.B.; supervision, S.Y. and V.C.; validation, V.C.; writingoriginal draft, S.B., B.D., P.-O.M., D.F. and V.C.; writing-review \& editing, S.B., B.D., P.-O.M., D.F. and V.C. All authors have read and agreed to the published version of the manuscript. 
Funding: This research study was jointly funded by ComAcross (www.onehealthsea.org/comacross (accessed on 1 January 2021)) and the SEAe (www.seaeproject.org (accessed on 1 January 2021)) projects.

Institutional Review Board Statement: Not applicable in this study.

Informed Consent Statement: Not applicable in this study.

Data Availability Statement: The data presented in this study are available on request from the corresponding author.

Acknowledgments: The authors thank the king people allowing the mosquito collection in their house and farms. The authors really want to thank the technicians for field sampling, SUOR Kimhuor, CHHUM Moeun, CHHUOY Kalyan, PANG Senglong, PENG Borin and SHRESTHA Kshitiz.

Conflicts of Interest: The authors declared no conflict of interest.

\section{References}

1. Lindahl, J. Japanese Encephalitis Virus in Pigs and Vectors in the Mekong Delta; Acta Universitatis Agriculturae Sueciae: Uppsala, Sweden, 2012; Volume 2012.

2. Campbell, G.L.; Hills, S.L.; Fischer, M.; A Jacobson, J.; Hoke, C.H.; Hombach, J.M.; A Marfin, A.; Solomon, T.; Tsai, T.F.; Tsu, V.D.; et al. Estimated global incidence of Japanese encephalitis: A systematic review. Bull. World Health Organ. 2011, 89, 766-774. [CrossRef] [PubMed]

3. Solomon, T.; Ni, H.; Beasley, D.W.C.; Ekkelenkamp, M.; Cardosa, M.J.; Barrett, A.D.T. Origin and Evolution of Japanese Encephalitis Virus in Southeast Asia. J. Virol. 2003, 77, 3091-3098. [CrossRef] [PubMed]

4. Ladreyt, H.; Durand, B.; Dussart, P.; Chevalier, V. How Central Is the Domestic Pig in the Epidemiological Cycle of Japanese Encephalitis Virus? A Review of Scientific Evidence and Implications for Disease Control. Viruses 2019, 11, 949. [CrossRef]

5. Hurk, A.F.V.D.; Ritchie, S.A.; Johansen, C.A.; MacKenzie, J.S.; Smith, G.A. Domestic Pigs and Japanese Encephalitis Virus Infection, Australia. Emerg. Infect. Dis. 2008, 14, 1736-1738. [CrossRef]

6. Takashima, I.; Watanabe, T.; Ouchi, N.; Hashimoto, N. Ecological Studies of Japanese Encephalitis Virus in Hokkaido: Interepidemic Outbreaks of Swine Abortion and Evidence for the Virus to Overwinter Locally. Am. J. Trop. Med. Hyg. 1988, 38, 420-427. [CrossRef] [PubMed]

7. Impoinvil, D.E.; Baylis, M.; Solomon, T. Japanese Encephalitis: On the One Health Agenda. Curr. Top. Microbiol. Immunol. 2012, 365, 205-247. [CrossRef]

8. Le Flohic, G.; Porphyre, V.; Barbazan, P.; Gonzalez, J.-P. Review of Climate, Landscape, and Viral Genetics as Drivers of the Japanese Encephalitis Virus Ecology. PLoS Negl. Trop. Dis. 2013, 7, e2208. [CrossRef]

9. Cleton, N.B.; Page, M.J.; Bowen, R.A.; Bosco-Lauth, A. Age-Related Susceptibility to Japanese Encephalitis Virus in Domestic Ducklings and Chicks. Am. J. Trop. Med. Hyg. 2014, 90, 242-246. [CrossRef]

10. Auerswald, H.; Ruget, A.-S.; Ladreyt, H.; In, S.; Mao, S.; Sorn, S.; Tum, S.; Duong, V.; Dussart, P.; Cappelle, J.; et al. Serological Evidence for Japanese Encephalitis and West Nile Virus Infections in Domestic Birds in Cambodia. Front. Vet. Sci. 2020, 7, 15. [CrossRef]

11. Ladreyt, H.; Auerswald, H.; Tum, S.; Ken, S.; Heng, L.; In, S.; Lay, S.; Top, C.; Ly, S.; Duong, V.; et al. Comparison of Japanese Encephalitis Force of Infection in Pigs, Poultry and Dogs in Cambodian Villages. Pathogens 2020, 9, 719. [CrossRef]

12. Liu, W.; Gibbons, R.V.; Kari, K.; Clemens, J.D.; Nisalak, A.; Marks, F.; Xu, Z.Y. Risk factors for Japanese encephalitis: A case-control study. Epidemiol. Infect. 2010, 138, 1292-1297. [CrossRef]

13. Keiser, J.; Maltese, M.F.; Erlanger, T.E.; Bos, R.; Tanner, M.; Singer, B.H.; Utzinger, J. Effect of irrigated rice agriculture on Japanese encephalitis, including challenges and opportunities for integrated vector management. Acta Trop. 2005, 95, 40-57. [CrossRef]

14. Cappelle, J.; Duong, V.; Pring, L.; Kong, L.; Yakovleff, M.; Prasetyo, D.B.; Peng, B.; Choeung, R.; Duboz, R.; Ong, S.; et al. Intensive Circulation of Japanese Encephalitis Virus in Peri-urban Sentinel Pigs near Phnom Penh, Cambodia. PLoS Negl. Trop. Dis. 2016, 10, e0005149. [CrossRef]

15. Higgins, D.A. A serological survey of pigs in Hong Kong for antibodies to Japanese encephalitis virus. Trop. Anim. Health Prod. 1970, 2, 23-27. [CrossRef]

16. Ura, M. Ecology of Japanese encephalitis virus in Okinawa, Japan. I. The investigation on pig and mosquito infection of the virus in Okinawa island from 1966 to 1976. Trop. Med. 1976, 18, 151-163.

17. Kumar, K.; Arshad, S.S.; Selvarajah, G.T.; Abu, J.; Toung, O.P.; Abba, Y.; Bande, F.; Yasmin, A.R.; Sharma, R.; Ong, B.L.; et al. Prevalence and risk factors of Japanese encephalitis virus (JEV) in livestock and companion animal in high-risk areas in Malaysia. Trop. Anim. Health Prod. 2018, 50, 741-752. [CrossRef]

18. Chan, I.P. Investigation of the HI titre of Japanese encephalitis of swine on Taiwan, Republic of China. Bull. Off. Int. Epizoot. 1968, $69,141-143$.

19. Gingrich, J.B.; Nisalak, A.; Latendresse, J.R.; Pomsdhit, J.; Paisansilp, S.; Hoke, C.H.; Chantalakana, C.; Satayaphantha, C.; Uechiewcharnkit, K. A longitudinal study of Japanese encephalitis in suburban Bangkok, Thailand. Southeast Asian J. Trop. Med. Public Health 1987, 18, 558-566. 
20. Do, Q.H.; Vu, T.Q.H.; Huynh, T.K.L.; Dinh, Q.T.; Deubel, V. Current situation of Japanese encephalitis in the south of Vietnam, 1976-1992. Trop. Med. 1994, 36, 202-214.

21. Lindahl, J.; Chirico, J.; Boqvist, S.; Thu, H.T.V.; Magnusson, U. Occurrence of Japanese Encephalitis Virus Mosquito Vectors in Relation to Urban Pig Holdings. Am. J. Trop. Med. Hyg. 2012, 87, 1076-1082. [CrossRef]

22. Morita, K.; Nabeshima, T.; Buerano, C. Japanese encephalitis. Rev. Sci. Tech. 2015, 34, 441-452. [CrossRef] [PubMed]

23. Leake, C. Arbovirus-mosquito interactions and vector specificity. Parasitol. Today 1992, 8, 123-128. [CrossRef]

24. Gajanana, A.; Thenmozhi, V.; Samuel, P.P.; Reuben, R. A community-based study of subclinical flavivirus infections in children in an area of Tamil Nadu, India, where Japanese encephalitis is endemic. Bull. World Health Organ. 1995, 73, 237.

25. Gingrich, J.B.; Nisalak, A.; Latendresse, J.R.; Sattabongkot, J.; Hoke, C.H.; Pomsdhit, J.; Chantalakana, C.; Satayaphanta, C.; Uechiewcharnkit, K.; Innis, B.L. Japanese Encephalitis Virus in Bangkok: Factors Influencing Vector Infections in Three Suburban Communities. J. Med. Èntomol. 1992, 29, 436-444. [CrossRef]

26. Gould, D.J.; Edelman, R.; Grossman, R.A.; Nisalak, A.; Sullivan, M.F. Study of Japanese encephalitis virus in Chiang Mai valley, Thailand IV. Vector studies. Am. J. Epidemiol. 1974, 100, 49-56. [CrossRef]

27. Leake, C.; Ussery, M.; Nisalak, A.; Hoke, C.; Andre, R.; Burke, D. Virus isolations from mosquitoes collected during the 1982 Japanese encephalitis epidemic in northern Thailand. Trans. R. Soc. Trop. Med. Hyg. 1986, 80, 831-837. [CrossRef]

28. Lord, J.S.; Al-Amin, H.M.; Chakma, S.; Alam, M.S.; Gurley, E.S.; Pulliam, J.R.C. Sampling Design Influences the Observed Dominance of Culex tritaeniorhynchus: Considerations for Future Studies of Japanese Encephalitis Virus Transmission. PLoS Negl. Trop. Dis. 2016, 10, e0004249. [CrossRef] [PubMed]

29. Olson, J.G.; Ksiazek, T.G.; Tan, R.; Atmosoedjono, S.; Lee, V.H.; Converse, J.D. Correlation of population indices of female Culex tritaeniorhynchus with Japanese encephalitis viral activity in Kapuk, Indonesia. Southeast Asian J. Trop. Med. Public Health. 1985 $16,337-342$.

30. Rajavel, A.R.; Kumar, N.P.; Natarajan, R.; Vanamail, P.; Rathinakumar, A.; Jambulingam, P. Morphological and molecular characterization of the ecological, biological and behavioural variants of the JE vector Culex tritaeniorhynchus: An assessment of its taxonomic status. J. Vector Borne Dis. 2015, 52, 40.

31. Nyari, N.; Singh, D.; Kakkar, K.; Sharma, S.; Pandey, S.N.; Dhole, T.N. Entomological and serological investigation of Japanese encephalitis in endemic area of eastern Uttar Pradesh, India. J. Vector Borne Dis. 2015, 52, 321-328. [PubMed]

32. Sudeep, A.B. Culex gelidus: An emerging mosquito vector with potential to transmit multiple virus infections. J. Vector Borne Dis. 2014, 51, 251-258. [PubMed]

33. Gajanana, A.; Rajendran, R.; Samuel, P.P.; Thenmozhi, V.; Tsai, T.F.; Kimura-Kuroda, J.; Reuben, R. Japanese encephalitis in south Arcot district, Tamil Nadu, India: A three-year longitudinal study of vector abundance and infection frequency. J. Med. Èntomol. 1997, 34, 651-659. [CrossRef]

34. Kramer, L.D.; Ebel, G.D. Dynamics of Flavivirus Infection in Mosquitoes. Adv. Appl. Microbiol. 2003, 60, 187-232. [CrossRef]

35. Murty, U.S.; Rao, M.S.; Arunachalam, N. The effects of climatic factors on the distribution and abundance of Japanese encephalitis vectors in Kurnool district of Andhra Pradesh, India. J. Vector Borne Dis. 2010, 47, 26-32. [CrossRef] [PubMed]

36. Reuben, R.; Samuel, P.P.; Gajanana, A.; Mani, T.R.; Thenmozhi, V. Mosquito Blood Feeding Patterns as a Factor in the Epidemiology of Japanese Encephalitis in Southern India. Am. J. Trop. Med. Hyg. 1992, 46, 654-663. [CrossRef]

37. Zinser, M.; Ramberg, F.; Willott, E. Scientific Note Culex quinquefasciatus (Diptera: Culicidae) as a potential West Nile virus vector in Tucson, Arizona: Blood meal analysis indicates feeding on both humans and birds. J. Insect Sci. 2004, 4, 20. [CrossRef] [PubMed]

38. Hasegawa, M.; Nam, V.S.; Tuno, N.; Takagi, M.; Yen, N.T. Influence of the Distribution of Host Species on Adult Abundance of Japanese Encephalitis Vectors-Culex vishnui Subgroup and Culex gelidus-In a Rice-Cultivating Village in Northern Vietnam. Am. J. Trop. Med. Hyg. 2008, 78, 159-168. [CrossRef]

39. Longbottom, J.; Browne, A.J.; Pigott, D.M.; Sinka, M.E.; Golding, N.; Hay, S.I.; Moyes, C.L.; Shearer, F.M. Mapping the spatial distribution of the Japanese encephalitis vector, Culex tritaeniorhynchus Giles, 1901 (Diptera: Culicidae) within areas of Japanese encephalitis risk. Parasites Vectors 2017, 10, 148. [CrossRef] [PubMed]

40. Chastel, C.; Rageau, J. Isolation of arbovirus in Cambodia from naturally infected mosquitoes. Med. Trop. 1966, 26, 391-400.

41. Self, L.S.; Shin, H.K.; Kim, K.H.; Lee, K.W.; Chow, C.Y.; Hong, H.K. Ecological studies on Culex tritaeniorhynchus as a vector of Japanese encephalitis. Bull. World Health Organ. 1973, 49, 41-47. [PubMed]

42. Ohba, S.-Y.; Van Soai, N.; Van Anh, D.T.; Nguyen, Y.T.; Takagi, M. Study of mosquito fauna in rice ecosystems around Hanoi, Northern Vietnam. Acta Trop. 2015, 142, 89-95. [CrossRef] [PubMed]

43. Abu Hassan, A.; Hamady, D.; Tomomitsu, S.; Michael, B.; Jameel, S.L.A. Breeding patterns of the JE vector Culex gelidus and its insect predators in rice cultivation areas of northern peninsular Malaysia. Trop. Biomed. 2010, 27, 404-416.

44. Lee, V.H.; Atmosoedjono, S.; Rusmiarto, S.; Aep, S.; Semendra, W. Mosquitoes of Bali Island, Indonesia: Common species in the village environment. Southeast Asian J. Trop. Med. Public Health 1983, 14, 298-307. [PubMed]

45. Nitatpattana, N.; Apiwathnasorn, C.; Barbazan, P.; Leemingsawat, S.; Yoksan, S.; Gonzalez, J. First isolation of Japanese encephalitis from Culex quinquefasciatus in Thailand. Southeast Asian J. Trop. Med. Public Health 2005, 36, 875.

46. Boyer, S.; Peng, B.; Pang, S.; Chevalier, V.; Duong, V.; Gorman, C.; Dussart, P.; Fontenille, D.; Cappelle, J. Dynamics and diversity of mosquito vectors of Japanese encephalitis virus in Kandal province, Cambodia. J. Asia-Pacific Èntomol. 2020, 23, 1048-1054. [CrossRef] 
47. Duong, V.; Choeung, R.; Gorman, C.; Laurent, D.; Crabol, Y.; Mey, C.; Peng, B.; Di Francesco, J.; Hul, V.; Sothy, H.; et al. Isolation and full-genome sequences of Japanese encephalitis virus genotype I strains from Cambodian human patients, mosquitoes and pigs. J. Gen. Virol. 2017, 98, 2287-2296. [CrossRef] [PubMed]

48. Clements, A.N. The Biology of Mosquitoes. Volume 2: Sensory Reception and Behaviour; CABI Publishing: New York, NY, USA, 1999.

49. Mwandawiro, C.; Boots, M.; Tuno, N.; Suwonkerd, W.; Tsuda, Y.; Takagi, M. Heterogeneity in the host preference of Japanese encephalitis vectors in Chiang Mai, northern Thailand. Trans. R. Soc. Trop. Med. Hyg. 2000, 94, 238-242. [CrossRef]

50. Tuno, N.; Tsuda, Y.; Takagi, M. How Zoophilic Japanese Encephalitis Vector Mosquitoes Feed on Humans. J. Med. Entomol. 2017, 54, 8-13. [CrossRef]

51. Boyer, S.; Marcombe, S.; Yean, S.; Fontenille, D. High diversity of mosquito vectors in Cambodian primary schools and consequences for arbovirus transmission. PLoS ONE 2020, e0233669. [CrossRef]

52. Morgan, K.; Somboon, P.; Walton, C.; Walto, C. Understanding Anopheles Diversity in Southeast Asia and its Applications for Malaria Control. In Anopheles Mosquitoes: New Insights into Malaria Vectors; IntechOpen: London, UK, 2013; pp. $327-355$.

53. Chakravarty, S.K.; Sarkar, J.K.; Chakravarty, M.S.; Mukherjee, M.K.; Mukherjee, K.K.; Das, B.C.; Hati, A.K. The first epidemic of Japanese encephalitis studied in India-virological studies. Indian J. Med. Res. 1975, 63, 77-82.

54. Vythilingam, I.; Oda, K.; Chew, T.K.; Mahadevan, S.; Vijayamalar, B.; Morita, K.; Tsuchie, H.; Igarashi, A. Isolation of Japanese encephalitis virus from mosquitoes collected in Sabak Bernam, Selangor, Malaysia in 1992. J. Am. Mosq. Control Assoc. 1995, 11, 94-98. [PubMed]

55. Kumari, R.; Kumar, K.; Rawat, A.; Singh, G.; Yadav, N.K.; Chauhan, L.S. First indigenous transmission of Japanese Encephalitis in urban areas of National Capital Territory of Delhi, India. Trop. Med. Int. Health 2013, 18, 743-749. [CrossRef]

56. Kuwata, R.; Trang, B.M.; Tsuda, Y.; Sawabe, K.; Nga, P.T.; Sasaki, T.; Yen, N.T.; Kobayashi, M.; Takagi, M.; Loan, D.P.; et al. Surveillance of Japanese Encephalitis Virus Infection in Mosquitoes in Vietnam from 2006 to 2008. Am. J. Trop. Med. Hyg. 2013, 88, 681-688. [CrossRef] [PubMed]

57. Mourya, D.T.; Ilkal, M.A.; Mishra, A.C.; Jacob, P.G.; Pant, U.; Ramanujam, S.; Mavale, M.S.; Bhat, H.R.; Dhanda, V. Isolation of Japanese encephalitis virus from mosquitoes collected in Karnataka state, India from 1985 to 1987. Trans. R. Soc. Trop. Med. Hyg. 1989, 83, 550-552. [CrossRef]

58. Vythilingam, I.; Oda, K.; Mahadevan, S.; Abdullah, G.; Thim, C.S.; Hong, C.C.; Vijayamalar, B.; Sinniah, M.; Igarashi, A. Abundance, Parity, and Japanese Encephalitis Virus Infection of Mosquitoes (Diptera: Culicidae) in Sepang District, Malaysia. J. Med. Ėntomol. 1997, 34, 257-262. [CrossRef] [PubMed]

59. Van Peenen, P.F.; Irsiana, R.; Saroso, J.S.; Joseph, S.W.; Shope, R.E.; Joseph, P.L. First isolation of Japanese Encephalitis virus from Java. Mil. Med. 1974, 139, 821-823. [CrossRef]

60. Olson, J.G.; Ksiazek, T.G.; Lee, V.H.; Tan, R.; Shope, R.E. Isolation of Japanese encephalitis virus from Anopheles annularis and Anopheles vagus in Lombok, Indonesia. Trans. R. Soc. Trop. Med. Hyg. 1985, 79, 845-847. [CrossRef]

61. Weng, M.H.; Lien, J.C.; Wang, Y.M.; Lin, C.C.; Lin, H.C.; Chin, C. Isolation of Japanese encephalitis virus from mosquitoes collected in Northern Taiwan between 1995 and 1996. J. Microbiol. Immunol. Infect. 1999, 32, 9. [PubMed]

62. Tangena, J.-A.A.; Thammavong, P.; Hiscox, A.; Lindsay, S.W.; Brey, P.T. The Human-Baited Double Net Trap: An Alternative to Human Landing Catches for Collecting Outdoor Biting Mosquitoes in Lao PDR. PLoS ONE 2015, 10, e0138735. [CrossRef]

63. Laurent, B.S.; Oy, K.; Miller, B.; Gasteiger, E.B.; Lee, E.; Sovannaroth, S.; Gwadz, R.W.; Anderson, J.M.; Fairhurst, R.M. Cow-baited tents are highly effective in sampling diverse Anopheles malaria vectors in Cambodia. Malar. J. 2016, 15, 440. [CrossRef]

64. Boreham, P.F.L.; Garrett-Jones, C. Prevalence of mixed blood meals and double feeding in a malaria vector (Anopheles sacharovi Favre). Bull. World Health Organ. 1973, 48, 605-614. [PubMed]

65. Lardeux, F.; Loayza, P.; Bouchité, B.; Chavez, T. Host choice and human blood index of Anopheles pseudopunctipennis in a village of the Andean valleys of Bolivia. Malar. J. 2007, 6, 8. [CrossRef]

66. Wooding, M.; Naudé, Y.; Rohwer, E.; Bouwer, M. Controlling mosquitoes with semiochemicals: A review. Parasites Vectors 2020, 13, 1-20. [CrossRef]

67. Walker, E.D.; Edman, J.D. The Influence of Host Defensive Behavior on Mosquito (Diptera: Culicidae) Biting Persistence. J. Med. Ėntomol. 1985, 22, 370-372. [CrossRef] [PubMed]

68. Harrington, L.C.; Edman, J.D.; Scott, T.W. Why Do Female Aedes aegypti (Diptera: Culicidae) Feed Preferentially and Frequently on Human Blood? J. Med. Ėntomol. 2001, 38, 411-422. [CrossRef] [PubMed]

69. Lyimo, I.N.; Ferguson, H.M. Ecological and evolutionary determinants of host species choice in mosquito vectors. Trends Parasitol. 2009, 25, 189-196. [CrossRef]

70. Dekker, T.; Takken, W.; Knols, B.G.; Bouman, E.; Laak, S.; Bever, A.; Huisman, P.W.T. Selection of biting sites on a human host by Anopheles gambiae s.s., An. arabiensis and An. quadriannulatus. Entomol. Exp. Appl. 1998, 87, 295-300. [CrossRef]

71. Takken, W.; Knols, B.G.J. Odor-mediated behavior of Afrotropical malaria mosquitoes. Annu. Rev. Ėntomol. 1999, 44, 131-157. [CrossRef] [PubMed]

72. Cooperband, M.F.; McElfresh, J.S.; Millar, J.G.; Cardé, R.T. Attraction of female Culex quinquefasciatus Say (Diptera: Culicidae) to odors from chicken feces. J. Insect Physiol. 2008, 54, 1184-1192. [CrossRef] [PubMed]

73. Colless, D.H. Notes on the Culicine Mosquitoes of Singapore: VII.-Host Preferences in Relation to the Transmission of Disease. Ann. Trop. Med. Parasit. 1959, 53, 259-267. [CrossRef] 
74. Reuben, R. Studies on the Mosquitoes of North Arcot District, Madras State, India Part 3. Host preferences for pigs, birds and some small mammals. J. Med. Ėntomol. 1971, 8, 258-262. [CrossRef] [PubMed]

75. Sirivanakarn, S. Medical entomology studies III. A revision of the subgenus Culex in the Oriental region (Diptera: Culicidae). Cont. Am. Entomol. Inst. 1976, 12, 1-271.

76. Mitchell, C.J.; Chen, P.S.; Boreham, P.F.L. Host-feeding patterns and behaviour of 4 Culex species in an endemic area of Japanese encephalitis. Bull. World Health Organ. 1973, 49, 293-299. [PubMed]

77. Whelan, P.I.; Hayes, G.; Carter, J.M.; Wilson, A.; Haigh, B. Detection of the exotic mosquito Culex gelidus in the Northern Territory. Commun. Dis. Intell. 2000, 24, 74-75. [PubMed]

78. Bram, R.A. Contributions to the Mosquito Fauna of Southeast Asia-II. The Genus Culex in Thailand (Diptera: Culicidae); Smithsonian Institution Offices: Washington, DC, USA, 1967.

79. Shimoda, H.; Tamaru, S.; Morimoto, M.; Hayashi, T.; Shimojima, M.; Maeda, K. Experimental Infection of Japanese Encephalitis Virus in Dogs. J. Vet. Med. Sci. 2011, 73, 1241-1242. [CrossRef] [PubMed]

80. Rattanarithikul, R.; Harbach, R.E.; Harrison, B.A.; Panthusiri, P.; Coleman, R.E.; Richardson, J.H. Illustrated keys to the mosquitoes of Thailand. VI. Tribe Aedini. Southeast Asian J. Trop. Med. Public Health 2010, 41, 1-225.

81. Rattanarithikul, R.; Harbach, R.E.; Harrison, B.A.; Panthusiri, P.; Coleman, R.E. Illustrated keys to the mosquitoes of Thailand V. Genera Orthopodomyia, Kimia, Malaya, Topomyia, Tripteroides, and Toxorhynchites. Southeast Asian J. Trop. Med. Public Health 2007, 38, 1-65.

82. Rattanarithikul, R.; Harrison, B.A.; Harbach, R.E.; Coleman, R.E.; Panthusiri, P. Illustrated keys to the mosquitoes of Thailand. IV. Anopheles. Southeast Asian J. Trop. Med. Public Health 2006, 37, 1-128.

83. Rattanarithikul, R.; Harrison, B.A.; Panthusiri, P.; Peyton, E.L.; Coleman, R.E. Illustrated keys to the mosquitoes of Thailand III. Genera Aedeomyia, Ficalbia, Mimomyia, Hodgesia, Coquillettidia, Mansonia, and Uranotaenia. Southeast Asian J. Trop. Med. Public Health 2006, 37, 1-85.

84. Rattanarithikul, R.; Harbach, R.E.; Harrison, B.A.; Panthusiri, P.; Jones, J.W.; Coleman, R.E. Illustrated keys to the mosquitoes of Thailand. II. Genera Culex and Lutzia. Southeast Asian J. Trop. Med. Public Health 2005, 36, 1-97.

85. Rattanarithikul, R.; Harrison, B.A.; Panthusiri, P.; Coleman, R.E. Illustrated keys to the mosquitoes of Thailand I. Background; geographic distribution; lists of genera, subgenera, and species; and a key to the genera. Southeast Asian J. Trop. Med. Public Health 2005, 36, 1-80.

86. Haycock, G.B.; Schwartz, G.J.; Wisotsky, D.H. Geometric method for measuring body surface area: A height-weight formula validated in infants, children, and adults. J. Pediatr. 1978, 93, 62-66. [CrossRef]

87. Wang, J.; Hihara, E. A unified formula for calculating body surface area of humans and animals. Graefe's Arch. Clin. Exp. Ophthalmol. 2004, 92, 13-17. [CrossRef]

88. R Core Team. R: A Language and Environment for Statistical Computing; R Foundation for Statistical Computing: Vienna, Austria, 2020; Available online: https: / / www.R-project.org (accessed on 20 January 2021).

89. Venables, W.N.; Ripley, B.D.; MASS Library of Functions. Modern Applied Statistics with S, 4th ed.; Springer: New York, NY, UAS, 2002; ISBN 0-387-95457-0.

90. Wickham, H. ggplot2: Elegant Graphics for Data Analysis; Springer: New York, NY, USA, 2016.

91. Wilke, C.O.; Wickham, H.; Wilke, M.C.O. Package 'Cowplot'. Streamlined Plot Theme and Plot Annotations for 'ggplot2'; 2019. Available online: https: / / www.R-project.org (accessed on 20 January 2021).

92. Delatte, H.; Bagny, L.; Brengue, C.; Bouetard, A.; Paupy, C.; Fontenille, D. The invaders: Phylogeography of dengue and chikungunya viruses Aedes vectors, on the South West islands of the Indian Ocean. Infect. Genet. Evol. 2011, 11, 1769-1781. [CrossRef] [PubMed]

93. Kent, R.J.; Norris, D.E. Identification of mammalian blood meals in mosquitoes by a multiplexed polymerase chain reaction targeting cytochrome B. Am. J. Trop. Med. Hyg. 2005, 73, 336-342. [CrossRef] [PubMed]

94. Vantaux, A.; Yao, F.; Hien, D.F.; Guissou, E.; Yameogo, B.K.; Gouagna, L.C.; Fontenille, D.; Renaud, F.; Simard, F.; Costantini, C.; et al. Field evidence for manipulation of mosquito host selection by the human malaria parasite, Plasmodium falciparum. BioRxiv 2018, 207183. [CrossRef] 